\title{
Genotoxicity and histopathological assessment of silver nanoparticles in Swiss albino mice
}

\author{
Oluyinka. A. Iyiola', Temitope F. Olafimihan'², Faoziyat A. Sulaiman ${ }^{3}$ \& Abass T. Anifowoshe ${ }^{1}$ \\ 1. Cell Biology and Genetics Unit, Department of Zoology, University of Ilorin, P.M.B 1515, llorin Kwara State, Nigeria; iyiola.oa@unilorin.edu.ng, \\ abassgenetic@gmail.com \\ 2. Ecology and Environmental Biology Unit, Department of Zoology, University of Ilorin, P.M.B 1515, Ilorin, Kwara State, Nigeria; \\ tfolafimihan@gmail.com \\ 3. Department of Biochemistry, University of Ilorin, P.M.B 1515, Ilorin, Kwara State, Nigeria; sulaiman.af@unilorin.edu.ng
}

Received 07-VII-2017 • Corrected 15-VIII-2017 • Accepted 01-IX-2017

\begin{abstract}
Silver nanoparticles (AgNPs) are widely used in industrial and medical applications. However, there is a growing concern about the potentialities of AgNPs to induce genotoxicity and DNA damage in humans. In this study, genotoxic and histopathological effects of AgNPs were investigated in mice using two well-characterized genetic assays: mouse bone marrow micronuclei (MN) and mouse sperm morphology assays. Swiss albino mice (total $\mathrm{N}=18$ ) were exposed to varying concentrations $(3,000 \mathrm{mg} / \mathrm{Kg}, 4,000 \mathrm{mg} / \mathrm{Kg}, 5,000 \mathrm{mg} / \mathrm{Kg}$ and $6,000 \mathrm{mg} /$ $\mathrm{Kg}$ ) of AgNPs for 5 consecutive days and observed for 30 days afterwards. Distilled water and colchicine were used as negative and positive controls, respectively. The MN assay showed that the frequency of micronuclei induction increased with AgNP concentration. Statistically significant differences $(p<0,05)$ were observed for the micronucleus frequency in the blood erythrocytes in all the test concentrations. Sperm head morphology assay also revealed various types of abnormal sperm head morphology and there was statistically significant increase in frequency of sperm abnormalities. Histopathological profiles of the liver also showed enlarge sinusoids, irregular portal tract, and dose-dependent vacuolation. These results suggest that AgNPs is genotoxic and represent a serious health risk to human heatlh.
\end{abstract}

Key words: silver nanoparticles, histopathological, sperm morphology, genotoxicity, micronucleus.
RESUMEN: Genotoxicidad y evaluación histopatológica de nanopartículas de plata en ratones albinos suizos. Las nanopartículas de plata (AgNPs) son ampliamente utilizadas en la industria y la medicina. Sin embargo, existe una creciente preocupación acerca de las potencialidades de los AgNPs para inducir genotoxicidad y daño del ADN en seres humanos. En este estudio, se investigaron los efectos genotóxicos e histopatológicos de los AgNPs en ratones utilizando dos ensayos genéticos: micronúcleos de médula ósea de ratón (MN) y ensayos de morfología de espermatozoides de ratón. Un total de 16 ratones de peso medio de $25-30 \mathrm{~g}$ se expusieron a concentraciones variables $(3,000 \mathrm{mg} /$ $\mathrm{Kg}, 4,000 \mathrm{mg} / \mathrm{Kg}, 5,000 \mathrm{mg} / \mathrm{Kg}$ y $6,000 \mathrm{mg} / \mathrm{Kg}$ ) de AgNP durante 5 días consecutivos y se observaron durante 30 días. Usé agua destilada y colchicina como controles negativos y positivos, respectivamente. El ensayo MN mostró que la frecuencia de inducción de micronúcleos aumentó con lasconcentraciones de AgNPs. En todas las concentraciones de ensayo hubo diferencias estadísticamente significativas $(p<0,05)$ en la frecuencia micronuclear de eritrocitos sanguíneos. Hubo varios tipos de morfología anormal de la cabeza del espermatozoo y aumento estadísticamente significativo en la frecuencia de anormalidades espermáticas. Los perfiles histopatológicos del hígado también mostraron sinusoides de aumento, tracto portal irregular y aparición de vacuolación dependiente de la dosis. Estos resultados sugieren que los AgNPs son genotóxicos y plantean un serio riesgo para la salud de los seres humanos considerando su uso en dispositivos médicos, hogar y varios tipos de productos de consumo.

Palabras clave: nanopartículas de plata, histopatológico, morfología espermática, genotoxicidad, micronúcleo.
In recent years, nanomaterials, also known as nanoparticles (NPs) are useful during production process of most of the consumer products used in our everyday life (Foldbjerg \& Autrup, 2013; Grosse, Evje \& Syversen, 2013; Contado, 2015). The application of nanoparticles (NPs) is widespread and has been extensively used in therapeutic and diagnostic agents, drug delivery systems, medical services, food containers and cosmetics (Echegoyen \& Nerin, 2013). ZnO-NP has biocidal effect and so there is safety concern of its usage (Demir, Kaya \& Kaya, 2014). Furthermore, potential genotoxic effects of nanoparticles have been a subject of debate among scientists (Heim et al., 2015). For example, recent study suggests that Zinc oxide NPs is potentially genotoxic and capable 
of inducing DNA double strand breaks (Heim et al., 2015). Similar study by Ghosh et al. (2012) also reported that Titanium dioxide ( $\mathrm{TiO} 2$ ) nanoparticle could be potentially genotoxic. A study carried out by Braydich-Stolle et al. (2010) revealed that AgNPs disrupt GDNF/Fyn kinase signaling in spermatogonial stem cells.

Previous studies have shown that silver nanoparticles (AgNPs) have strong antibacterial, antiviral and antifungal effects (Wijnhoven et al., 2009; Birgit et al., 2013). Due to these useful properties AgNPs have been used in the manufacture of most consumer products in recent times (Birgit et al., 2013) and as a matter of fact AgNPs is among the most popular nanomaterials used in material science, most importantly as the constituents for treating wound and burn related infections; drug delivery in cancer and retinal therapies (Kalishwaralal, Barathmanikanth, Pandian, Deepak \& Gurunathan, 2010). However, there is a growing concern on the safety of nanoparticles. More worrisome on the safety of these nanoparticles is the fact that some of them are used in food additives (Contado, 2015), cosmetics and coatings (Heim et al., 2015). Quite a number of toxicological studies have been carried out to show that AgNPs has toxic effects on aquatic animals (Asharani, Wu, Gong \& Valiyaveetti, 2008; Bar-llan, Albrecht, Fako, Furgeson, 2009; Bilberg, Doving, Beedholm \& Baatrup, 2011).

In a similar study by Kim et al. (2008), AgNPs was reported to exert genotoxic effects in rats (Kim et al., 2008; and in humans: Kim, Kim, Lee, Oh \& Chung, 2011). Results from Grosse et al. (2013) also suggested that exposure of rat brain endothelial RBE4 cells to AgNPs impaired the membrane function of these cells although the effect was shown to be dependent on particle size, surface area, exposure time and dose. In vitro and in vivo genotoxicity studies by Ghosh et al. (2012) suggested that AgNPs is capable of producing reactive oxygen species (ROS) and inducing apoptosis and necrosis in both plant and animal system. AgNPs can enter the cell by diffusion or endocytosis to cause mitochondrial dysfunction leading to the damage or mutation of protein and nucleic acid ultimately inhibiting cell proliferation (Ahamed, 2010). Imani et al.,(2015) have reported that AgNPs can induce significant changes in hematological profiles of rainbow trout. Cheraghi et al. (2013) also reported significant decrease in haematological parameters (erythrocyte, leucocyte and haemoglobin counts) of rats that were gavaged with AgNPs. It has also been documented that AgNPs could penetrate reproductive tissue through biological barriers which may in turn reduce sperm viability and alter cellular functions, as well as embryo development (Taylor et al., 2012). Despite widely accepted and demonstrated benefits of AgNPs particularly in manufacture of consumer products, recent evidences from studies conducted have implicated AgNPs as a toxic agent which no doubt could be worrisome to the populace. Therefore this study investigated genotoxic and histopathological effects induced by oral exposure of mice to varying concentrations of AgNPs using the sperm morphology and micronucleus assays.

\section{MATERIALS AND METHODS}

Test chemicals: The silver nanoparticle (AgNPs) was purchased from Sigma Aldrich, Germany with CAS number 1401-55-4. The particle size was $20 \mathrm{~nm}$ with a concentration of $0.02 \mathrm{mg} / \mathrm{ml}$ in distilled water. The nanoparticle was in liquid form, colourless, odourless and delivered in a golden-brown bottle. Colchicine $0.05 \%$ was prepared for positive control, Eosin Y stain 1\%, Giemsa stain 5\% and powdered form of Maygrunwald stain were used.

Experimental Animal: Swiss albino mice (Mus musculus) of between $25-30 \mathrm{~g}$ body weight were obtained from Department of Biochemistry, University of Ilorin, Nigeria, and acclimatized for two weeks before the start of the experiment. They were kept in plastic cages with beddings made of saw dust all through the period of the experiment. Animals were maintained under standard hygienic conditions with alternate $12 \mathrm{~h}$ light and dark cycle and given free access to mice chow and clean water ad libitum. Handling of animals was consistent with relevant guidelines on the care and use of laboratory animals (National Research Council, 2011). The mice were randomly divided into six groups of three animals per group. The details of animal groupings are as shown below:

- Group A served as negative control and received $1,0 \mathrm{ml}$ of distilled water.

- Group B received 3,000 mg/Kg of AgNPs

- Group C received 4,000mg/Kg of AgNPs

- Group D received 5,000 mg/Kg of AgNPs

- Group E received $6,000 \mathrm{mg} / \mathrm{Kg}$ of AgNPs.

- Group F served as positive control and received 25mg/ $\mathrm{Kg}$ of colchicine.

The mice were administered various concentrations of AgNPs orally for five consecutive days using cannula and left for 30 days thereafter. Group F was administered colchicine and sacrificed 4 hours later. 
Micronucleus assay: The procedure of Bakare et al. (2009) was adopted with minor modifications for the micronucleus assay. After 5 consecutive days of IP exposure and 30 days of observation, six groups of mice (4 mice per group, 20-28g ) administered with varying concentrations of the AgNPs $3,000 \mathrm{mg} / \mathrm{kg}, 4,000 \mathrm{mg} / \mathrm{Kg}, 5,000 \mathrm{mg} /$ $\mathrm{Kg}, 6,000 \mathrm{mg} / \mathrm{Kg}$ body weight were sacrificed including mice in the negative control group. About 4 hour prior to sacrifice, mice in the positive control group were injected with an aqueous solution of colchicine $(2,5 \mathrm{mg} / \mathrm{Kg}$ bw, IP). Bone marrow preparation for micronuclei assessment was according to the procedure of Bakare et. al., (2009). Briefly, the animals were sacrificed by cervical dislocation. The femurs were removed from each and bone marrow flushed from the bones with Foetal Bovine Serum (Sigma Aldrich Cheme GmbH, Germany). Cells were centrifuged at 3,000rpm for $10 \mathrm{~min}$ and slides stained with May-Grunwald and Giemsa stains. At least 1,000cells/ animals were scored for micronuclei in polychromatic erythrocytes (MNPCE). The differential staining of PCEs (bluish-purple) and normochromatic erythrocytes (NCEs, pinkish-orange), and the relative size of the erythrocytes, are indices for differentiating them.

Sperm morphology assay: Sperm cell abnormalities test was carried out using standard procedures of Wyrobek, Gordon and Burkhart (1983) and Bakare et al. (2009). A single intraperitoneal (IP) injection of $0,5 \mathrm{~mL}$ of the respective dosage group was administered to the mice daily for 5 consecutive days. The same volume but were injected with an aqueous solution of colchicine $(2,5 \mathrm{mg} / \mathrm{Kg} \mathrm{bw}, \mathrm{IP})$ and double distilled water was administered to mice in the positive and negative control groups respectively. Mice were sacrificed and sperm cells were sampled from the cauda epididymes after $35^{\text {th }}$ day from the first exposure. Four mice per dosage group were sacrificed by cervical dislocation and their cauda epididymes removed; sperm suspensions were then prepared from the cauda of each testis by mincing the cauda in normal saline and $1 \%$ eosin $Y$ stain. The slides were air-dried and coded for subsequent microscopic examination at $\times 1000$. For analysis, 1000 sperm cells were assessed from each mouse for sperm morphological abnormalities according to the criteria of Wyrobek and Bruce (1975) and Bakare et al. (2009).

Histological examination: The preparation of tissue sections for histological examination under light microscope followed the standard embedding and H-E staining protocol. Testes and liver were removed from the animals used for test and control. Slices of these organs were fixed in $10 \%$ neutral buffered formalin. Fixation was carried out after 48 hours after which organs were dehydrated by passing through ascending order of ethyl alcohol-water concentrations, cleared in xylene and sequentially embedded in paraffin wax blocks using rotary microtome. Tissue sections of 3-5 $\mu$ m thick were cut, stained with Haematoxylin-eosin ( $\mathrm{H}-\mathrm{E})$, then mounted in neutral DPX medium for morphological evaluation before microscopic examination at magnification $400 \mathrm{x}$.

Statistical analysis: Data was analyzed using the analysis of variance (ANOVA) and Duncan multiple range test on SPSS package. The data were presented as Mean \pm Standard error of mean. Group mean value at $5 \%$ level of confidence $(p<0.05)$ was considered significant.

\section{RESULTS}

Results of frequency of nuclear abnormalities in mice treated with AgNPs are shown in Table 1. This revealed that frequency of nuclear abnormalities is concentration-dependent such that at $6000 \mathrm{mg} / \mathrm{Kg}$ of $\mathrm{AgNps}$, the total nuclear abnormalities (235) compared with negative control (24).

TABLE 1

Frequency of nuclear abnormalities in mice treated with various concentrations of AgNPs

\begin{tabular}{lcccccccccc}
\multicolumn{1}{c}{ Concentration $(\mathrm{mg} / \mathrm{Kg})$} & MN & BN & EN & CN & PM & FG & KS & Total & Mean & Sd \\
Negative control & 08 & 05 & 03 & 02 & 03 & 02 & 01 & 24 & 3,43 & 2,37 \\
3000 & 102 & 46 & 11 & - & 03 & - & - & 162 & 40,50 & 45,05 \\
4000 & 69 & 85 & 32 & 2 & 4 & - & - & 192 & 38,40 & 37,61 \\
5000 & 136 & 35 & 34 & - & - & 01 & - & 206 & 51,50 & 58,51 \\
6000 & 70 & 75 & 33 & 18 & 39 & - & - & 235 & 47,00 & 58,51 \\
Positive control & 116 & 105 & 55 & 6 & 3 & 8 & 13 & 306 & 43,71 & 49,00 \\
\hline
\end{tabular}

*MN: micronucleus, BN: binucleated, EN: enucleated , CN: creanated, PM: polymorphic, FG: fragmented, KS: kidney shape. 
TABLE 2

Summary of sperm cell abnormality types and frequency in male mice after 35days of exposure to AgNPs

\begin{tabular}{|c|c|c|c|c|c|c|c|c|}
\hline Concentration $/(\mathrm{mg} / \mathrm{Kg})$ & WHA & $\mathrm{AH}$ & FT & $\mathrm{NH}$ & $\mathrm{TH}$ & $\mathrm{FH}$ & LT & Total Abnormalities \\
\hline Distilled water & 1 & - & 1 & 0 & 1 & --- & --- & 03 \\
\hline 3000 & 29 & 30 & 62 & 8 & 3 & --- & --- & 132 \\
\hline 4000 & 27 & 10 & 58 & - & --- & 37 & 1 & 133 \\
\hline 5000 & 19 & 20 & 80 & 4 & --- & 10 & --- & 133 \\
\hline 6000 & 43 & 47 & 73 & 7 & 6 & 14 & 10 & 200 \\
\hline Total (mg/Kg) & 149 & 127 & 290 & 15 & 4 & 61 & 23 & 680 \\
\hline
\end{tabular}

*WHA- Wrong Hook Attachment, AH- Amorphous Head, FT- Folded Tail, NH- No Hook, TH-Two Heads, FH- Folded Hook, LT- Long Tail.

Results of frequency of sperm cell morphology abnormalities in mice treated with AgNPs are shown in Table 2. These results revealed that frequency of abnormalities reached its peak at $6000 \mathrm{mg} / \mathrm{Kg}$ of AgNps, the total sperm head abnormalities was 200 compared with negative control (distilled water) which was 3.

Frequency of $\mathrm{MN}$ and other nuclear abnormalities observed in mice treated with AgNPs are shown in Figure 1, 2 and 3. MN frequency reached its peak at $6000 \mathrm{mg} /$ $\mathrm{Kg}$ of AgNps indicating that the induction of $\mathrm{MN}$ was concentration-dependent.
Histopathological results of the liver are presented in plates A, B, C and D of Figure 4 and histopathological results of the rat testis after exposure to AgNPs are shown in plates $A, B, C$ and $D$ of Figure 5 .

\section{DISCUSSION}

Genotoxic and cytotoxic potentials of AgNPs in this study are demonstrated in the results of $\mathrm{MN}$ and abnormal morphology sperm cells. Concentration-dependent increases in micronuclei and abnormal sperm cells as

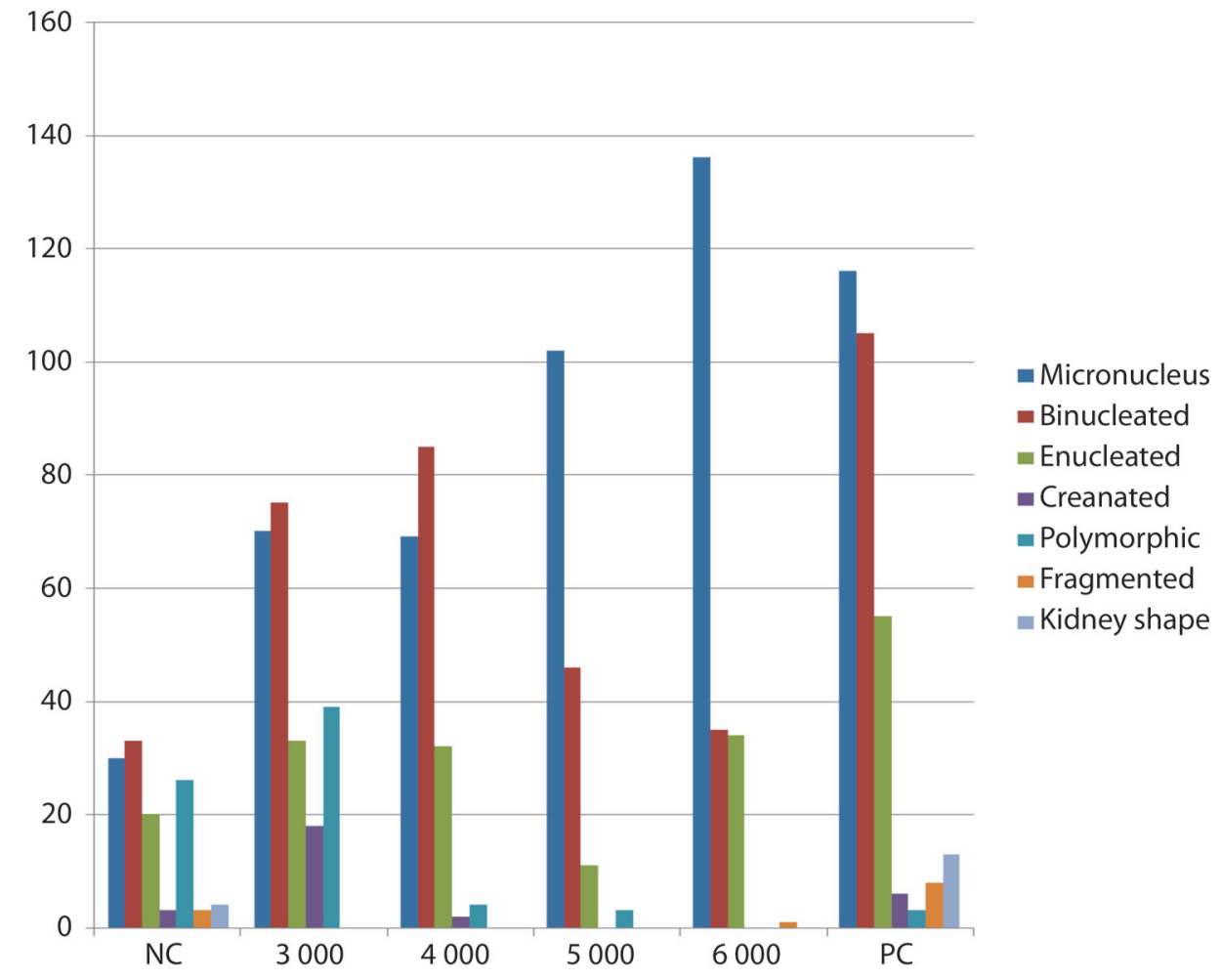

Fig 1. Frequency of MN and other various type of nuclear abnormalities observed in mice treated with AgNPs. 

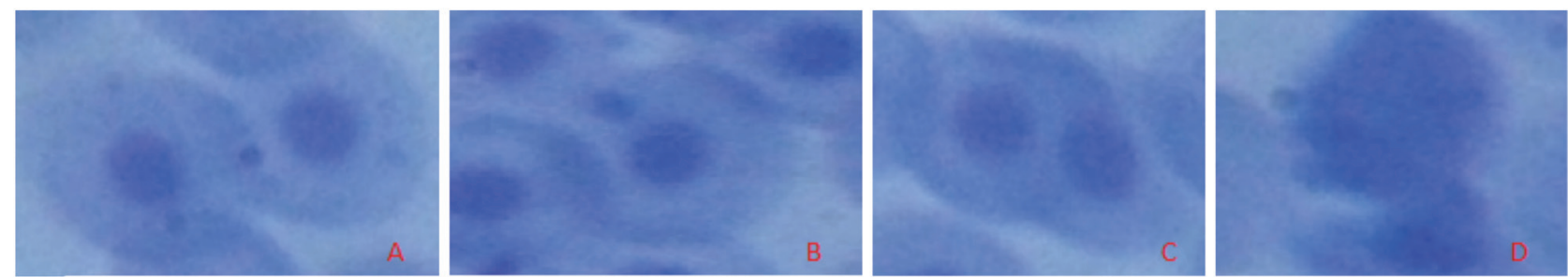

Fig 2. Various types of abnormal sperm cells observed. (Magnification 1000×). A. Cell with normal nucleus, B. Micronucleus cell, C. Binucleated cell, D. Cell with fragmented nucleus.
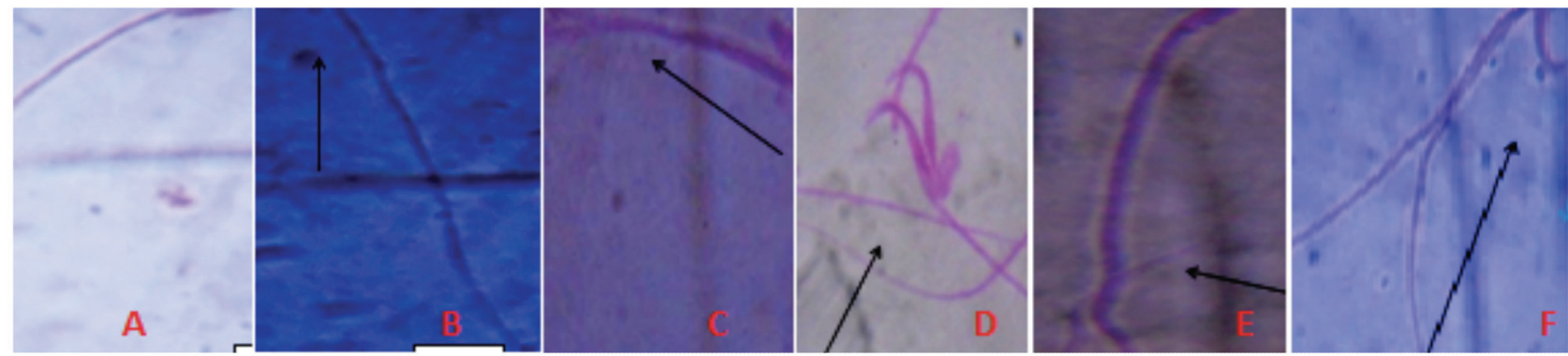

Fig 3. Different types of Sperm cell Abnormalities observed after exposure to AgNPs A. Normal mouse sperm cell, B. No hook, C. Amorphous head, D. Double heads, E. Long tail, F. Wrong hook attachment (Magnification 1000x).
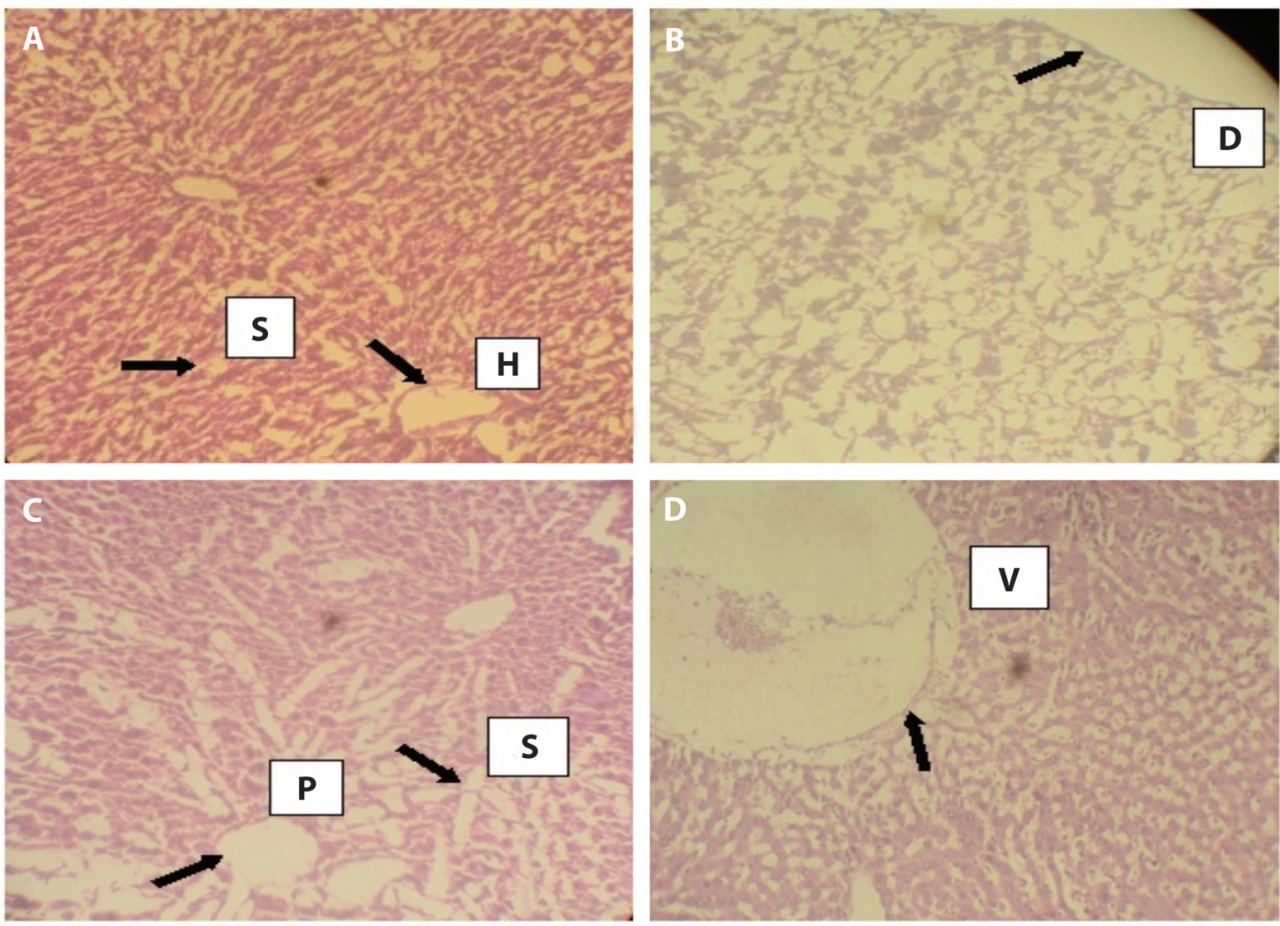

Fig 4. Photomicrographs of the histopathology of the liver. A. normal liver with slightly enlarged hepatic tract and irregular sinusoids (treated with distilled water), B. grossly distorted architecture of the liver tissue $\mathbf{C}$. irregular portal tracts surrounded by enlarged sinusoids, D. positive control group with colchicines showing an abnormal liver with high level of vacuolation. S. Sinusoids, H. Hepatic Tract, D. Distortion, P. Portal Tract, V. Vacuolation. 

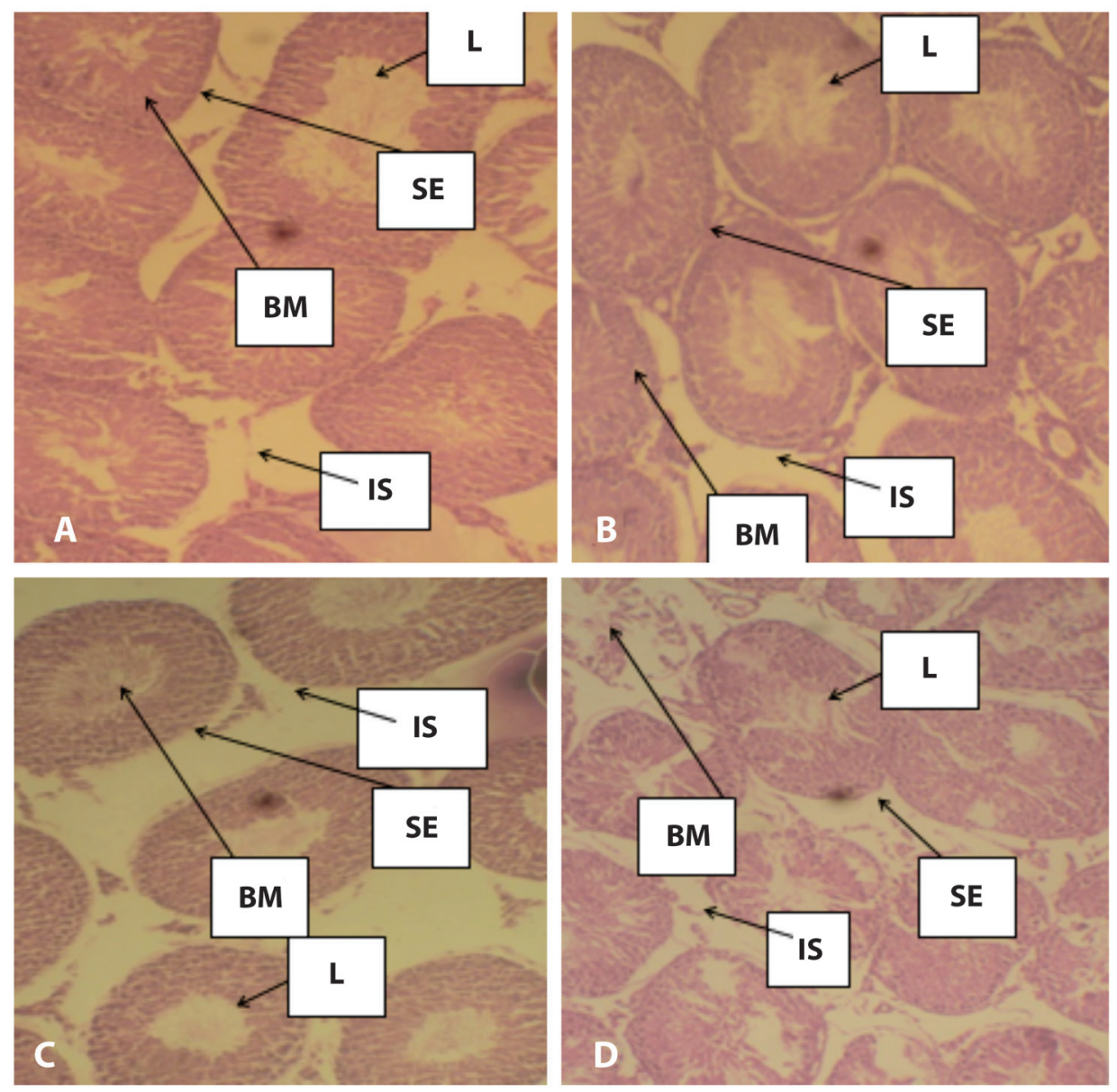

Fig 5. Photomicrographs of mices' testes. A. There was normal architecture of seminiferous tubules in mice group treated with distilled water, B. Showed slight infiltration of the seminiferous tubules, C. Slight hypertrophic seminiferous tubules but with high infiltration after exposure to $6,000 \mathrm{mg} / \mathrm{kg}$ of AgNPs, D. Severe hypertrophic seminiferous tubules after exposure to colcichine in positive control group. L. Lumen of seminiferous tubule, BM. Basal membrane, IS. Interstisium,. SE. Seminiferous epithelium.

observed in this study suggest DNA damage and genotoxic effects of AgNPs. One possible reason for this observation could be that once the cells take up the AgNPs, cell cycle arrest might have occurred Therefore, different DNA repair mechanisms available in the cell, apoptotic propensities and cellular integrity of the whole genome may have all been compromised by the exposure of the cells to AgNPs. It is also plausible to suggest that AgNPs or liberated silver ion may have interacted directly with proteins or genomic DNA thereby causing disruption in DNA backbone and possible genomic imbalance. Another piece of evidence for concentration-dependent and statistically significant increase in abnormal sperm head morphology observed in this study is that AgNPs has been previously reported by Braydich-Stolle et al. (2010) to disrupt GDNF/Fyn kinase signaling in spermatogonial stem cells. Foldbjerg and Autrup (2013) also attributed these abnormalities to possible formation of reactive oxygen species (ROS) by AgNPs, which then interacts with and damage proteins or DNA. Study carried out by Ghosh et al. (2012) has also previously suggested that AgNPs can induce programmed cell death (apoptosis) and necrosis in both plant and animal systems. Ghosh et al. (2012) reported that AgNPs can possibly induce DNA breakage in human lymphocytes.

The structure of the sperm cell is very essential for fertilization and pregnancy outcome. Sperm abnormalities have long been associated with male infertility and sterility in most species (Saacke, 2001). Increase in induction of abnormal sperm cell morphology observed in this study is in consonance with the work of Kruszewski et al. (2011) who reported that AgNPs could react with cellular DNA and stimulate inflammation, oxidative damage and cellular dysfunction that lead to genetic 
mutation and sperm cells with abnormal morphology. In contrast, with the work of Miresmaeili et al. (2013), the frequency of sperm abnormalities in this study was independent of treatment concentrations. This could be due to the different sizes of AgNPs used in both studies. Mangelsdorf, Buschmann and Orthen (2003) reported that the decrease in the total sperm count, increase in abnormal sperm shape, impair in stability of sperm chromatin or damaged in sperm DNA results in the disruption of spermatogenesis at any stage of cell differentiation. It is not surprising that were statistically significant increase in abnormal sperm cell induction observed in this study because previous study has also suggested that AgNPs can cause DNA breakage in human lymphocytes (Ghosh et al., 2012).

Infiltrations of the seminiferous tubule observed in mice after exposure to varying concentrations of AgNPs may possibly suggest that genotoxic effects of AgNPs. This result is consistent with a study carried out by Amin, et al., (2015) which reported that accumulation of silver in different organs occurred in the order; lung $>$ liver $>$ kidney>testes. The enlarged and irregular sinusoidal spaces observed in liver of exposed mice could be due to degeneration of the hepatocytes caused by the genotoxic action of the AgNPs. Abdelhalim and Jarrar (2011) and Alizadeh et al. (2016) have also previously reported hepatocytes atrophy and dilation of sinusoidal space in the liver of mice treated with gold and silver nanoparticles. Park et al. (2010) however, reported a different accumulation trend of kidney>testis $>$ liver $>$ brain $>$ lung. Yavasoglua et al. (2008) and Takeda et al. (2009) suggested that sloughing is caused by the effects of the chemical on microtubules and intermediate filaments of the sertoli cells which may naturally lead to tubular atrophy. In summary, this study suggests that AgNPs is genotoxic to mice and could possibly exert the same effect in human. We therefore suggest that further cellular and molecular investigations should be done to better understand the molecular mechanisms involved.

\section{REFERENCES}

Abdelhalim, M. A. K., \& Jarrar B. M. (2011). Gold nanoparticles administration induced prominent inflammatory, central vein intima disruption, fatty change and Kupffer cells hyperplasia. Lipids in Health and Disease, 10(1), 133. doi:10.1186/1476-511X-10-133

Ahamed, M. (2010). Silver nanoparticles induced heat shock protein, oxidative str essapoptosis in Drosophila melanogaster. Toxicology and Applied Pharmacology, 242, 263-269. doi:10.1016/j.taap.2009.10.016
Alizadeh, Z., Mahmoudian, Z. G., Sohrabi, M., Lahoutian, H., Assari, M., \& Alizadeh, Z. (2016). Histological alterations and apoptosis in rat liver following silver nanoparticle intraorally administration. Entomology and Applied Science Letters, 3(5), 27-35.

Amin, Y., Hawas, A. M., El-Batal, A. I., Seham, H. M., \& Mostafa, E. (2015): Evaluation of Acute and Subchronic Toxicity of Silver Nanoparticles in Normal and Irradiated Animals. British Journal of Pharmacology and Toxicology, 6, 22-38

Asharani P.V.,Wu,Y.L., Gong,Z., \&Valiyaveetti, S. (2008).Toxicity of silver nanoparticles inzebrafish models. Nanotechnology, 19(25), 55-102. doi:10.1088/0957-4484/19/25/255102

Bakare, A., Okunola, A., Adetunji, A., \& Hafeez B. (2009). Genotoxicity assessment of a pharmaceutical effluent using four bioassays. Genetics and Molecular Biology, 32(2), 373-381. doi:10.1590/S1415-47572009000200026

Bar-llan, O., Albrecht, R. M., Fako, V. E., \& Furgeson, D. Y. (2009). Toxicity assessments of multisized gold and silver nanoparticles in Zebrafish embryos. Small 5(16), 1897-1910. doi:10.1002/smll.200801716

Bilberg, K., Doving, K. B., Beedholm, K., Baatrup, E. (2011). Silver nanoparticles disrupt olfaction in Crucian carp (Carassius carassius) and Eurasian perch (Perca fluviatilis). Aquatic Toxicology, 104, 145-152. doi:10.1016/j. aquatox.2011.04.010

Braydich-Stolle, L. K., Lucas, B., Schrand, A., Murdock, R. C., Lee, T., Schlager, J. J., \& Hofmann, M. C. (2010): Silver nanoparticles disrupt GDNF/Fyn kinase signaling in spermatogonial stem cells. Toxicological Sciences, 116, 577-589.

Braydich-Stolle, L., Hussain, S., Schlager, J. J., Hofmann, M. C. (2005). In vitro cytotoxicity of nanoparticles in mammalian germline stem cells. Toxicological Sciences, 88, 412-9. doi:10.1093/toxsci/kfi256

Cheraghi, J., Hosseini, E., Hoshmandfar, R., \& Sahraei, R. (2013). Hematologic parameters study of male and female rats administrated with different concentrations of silver nanoparticles. International Journal of Agriculture and Crop Sciences, 5, 789-796.

Contado. C. (2015) Nanomaterials in consumer products: a challenging analytical problem. Frontiers in Chemistry, 3, 48. doi:10.3389/fchem.2015.00048

Demir, E., Kaya., N., \& Kaya, B. (2014). Genotoxic effects of zinc oxide and titanium dioxide nanoparticles on root meristem cells of Allium cepa by comet assay. Turkish Journal of Biology, 38, 31-39. doi:10.3906/biy-1306-11

Echegoyen, Y., \& Nerin, C. (2013): Nanoparticle release fromnano-silver antimicrobial food containers. Food and Chemical Toxicology, 62, 16-22. doi:10.1016/j. fct.2013.08.014

Foldbjerg, R., \& Autrup, H. (2013). Mechanisms of Silver Nanoparticle Toxicity. Archives of Basic and Applied Medicine, 1(1), 5-15. 
Gaiser, B., Hirn, S., Kermanizadeh, A., Kanase, N., Fytianos, K., Wenk, A., Haberl, N., Brunelli, A., Kreyling, W. G., \& Stone, V. (2013). Effects of Silver Nanoparticles on the Liver and Hepatocytes In Vitro. Toxicological Sciences, 131(2), 537547. doi:10.1093/toxsci/kfs306

Ghosh, M, Manivannan J, Sinha, S, Chakraborty, A., Mallickd, S. K., Bandyopadhyay, M., \& Mukherjee, A. (2012). In vitro and in vivo genotoxicity of silver nanoparticles. Mutation Research, 749, 60- 69. doi:10.1016/j. mrgentox.2012.08.007

Grosse, S., Evje, L., \& Syversen, T (2013). Silver nanoparticle-induced cytotoxicity in rat brain endothelial cell culture. Toxicology in Vitro, 27, 305-313. doi:10.1016/j. tiv.2012.08.024

Heim, J., Felder, E., Tahir, N.M., Kaltbeitzel, A. Heinrich,a, U.R., Brochhausen, C., Mailänder, V., Tremel., W and Brieger., J. (2015). Genotoxic effects of Zinc oxide nanoparticles. Nanoscale, 7, 8931-8938.

Imani, M., Halimi, M., \& Khara, H. (2015). Effects of silver nanoparticles (AgNPs)

Kalishwaralal, K., Barathmanikanth, S., Pandian, S. R., Deepak, V., \& Gurunathan, S. (2010): Silver nanoparticle, a trove for retinal therapies. Journal of Controlled Release, 145, 76-90. doi:10.1016/j.jconrel.2010.03.022

Kim, H. R., Kim, M. J., Lee, S. Y., Oh, S. M., \& Chung, K. H. (2011). Genotoxic effects of silver nanoparticles stimulated by oxidative stress in human normal bronchial epithelial (BEAS-2B) cells. Mutation Research, 726(2), 129-135. doi:10.1016/j.mrgentox.2011.08.008

Kim, Y. S., Kim, J. S., Cho, H. S., Rha, D. S., Kim, J. M., Park, J. D., Choi, B. S., Lim , R., Chang, H. K., Chung, Y. H., Kwon, I. H., Jeong, J., Han, B. S., \& Yu, I. J. (2008). Twentyeight-day oral toxicity, genotoxicity and gender-related tissue distribution of silver nanoparticles in Sprague Dawley rats. Inhalation Toxicology, 20, 575-83. doi:10.1080/08958370701874663

Kruszewski, M., Brzoska, K., Brunborg, G., Asare, N., Dobrzynska, M., Duzinska, M., Fjellsbo, L. M., Georgantzopoulou, A., Gromadzka-Ostrowska, J., \& Gutleb, A. C. (2011). Toxicity of Silver Nanomaterials in Higher Eukaryotes. Advances in Molecular Toxicology, 5, 179 - 259. doi:10.1016/ B978-0-444-53864-2.00005-0

Mangelsdorf, I., Buschmann, J., \& Orthen, B. (2003). Some aspects relating to the evaluation of the effects of chemicals on male fertility. Regulatory Toxicology and Pharmacology, 37, 356 - 369. doi:10.1016/S0273-2300(03)00026-6

Miresmaeili, S., Halvaei, I., Fesahat, F., Fallah, A., Nikonahad, N., \& Taherinejad, M. (2013). evaluating the role of silver nanoparticles on acrosomal reaction and spermatogenic cells in rat. Iranian Journal of Reproductive Medicine, $11,423-430$.

National Research Council. (2011). Guide for the Care and Use of Laboratory Animals. 8th Ed., Washington, DC.: National Academies Science on hematological parameters of rainbow trout, Oncorhynchus mykiss. Comp Clin Pathol, 24, 491-495. doi:10.1007/s00580-014-1927-5

Park, E., Bae, E., Yi, J., Kim, Y., Choi, K., Hee, S., Yoon, J., Lee, B., \& Park, K. (2010). Repeated-dose toxicity and inflammatory responses in mice by oral administration of silver nanoparticles. Environmental Toxicology and Pharmacology., 30, 162-168. doi:10.1016/j.etap.2010.05.004

Saacke, R. G. (2001): What is BSE-SFT standards: the relative importance of sperm morphology: an opinion. Proceedings Society Theriogenology, 113, 81-87.

Takeda, K., Suzuki, K. I., Ishihara, A., Kubo-Irie, M., Fujimoto, R., Tabata, M., ... \& Sugamata, M. (2009). Nanoparticles transferred from pregnant mice to their offspring can damage the genital and cranial nerve systems. Journal of Health Science, 55(1), 95-102. doi/10.1248/jhs.55.95

Taylor, U., Barchanski, A., Garrels, W., Klein, S., Kues, W., Barcikowski, S., \& Rath, D. (2012). Toxicity of gold nanoparticles on somatic and reproductive cells. In Nano-biotechnology for biomedical and diagnostic Research (pp. 125-133). Springer Netherlands. doi:10.1007/978-94-007-2555-3_12

Wijnhoven, S. W., Peijnenburg, W. J., Herberts, C. A., Hagens, W. I., Oomen, A. G., Heugens, E. H., ... \& Dekkers, S. (2009). Nano-silver-a review of available data and knowledge gaps in human and environmental risk assessment. Nanotoxicology, 3(2), 109-138. http://www.tandfonline. com/doi/full/10.1080/17435390902725914

Wyrobek, A. J., \& Bruce, W. R. (1975). Chemical induction of sperm abnormalities in mice. Proceedings of the National Academy of Sciences, 72(11), 4425-4429. doi:10.1073/pnas.72.11.4425

Wyrobek, A. J., Gordon, L. A., Burkhart, J. G., Francis, M. W., Kapp, R. W., Letz, G., ... \& Whorton, M. D. (1983). An evaluation of the mouse sperm morphology test and other sperm tests in nonhuman mammals: A report of the US Environmental Protection Agency Gene-Tox Program. Mutation Research/Reviews in Genetic Toxicology, 115(1), 1-72. Yavasoglua, A., Ali Karaaslan, M., UyaniKgila, Y., Sayim, F., Atesa, U., \& Yavasoglub, N. U. K. (2008). Toxic effects of anatoxin-a on testes and sperm counts of male mice. Experimental and Toxicologic Pathology, 60, 391-396. doi:10.1016/0165-1110(83)90014-3 